\title{
Schumpeter and his contemporaries-précis and road marks
}

\author{
Uwe Cantner $^{1} \cdot$ Kurt Dopfer $^{2}$
}

Published online: 7 April 2015

(C) Springer-Verlag Berlin Heidelberg 2015

The late Mark Perlman left a basket of project ideas on his desk, but the proposal to provide an authentic picture of Schumpeter — of the man and his work - by situating him within the context of his contemporaries appears particularly worthwhile to the editors of this collection of papers.

Perlman was one of Schumpeter's "master" editors. Significantly, he edited (or reedited) two of Schumpeter's major contributions to doctrinal history, History of Economic Analysis (1954/1994) and Ten Great Economists. From Marx to Keynes (1951/1997). The introductory essays to these volumes are showpieces, most helpful for novices in obtaining a grasp of the "essential Schumpeter", and, for the cognoscenti, providing original and often new interpretations.

However, Perlman was also a distinguished historian of economic thought in his own right. His editorial introductions represent but two particular plants in the garden of his general contributions to doctrinal history, which include his seminal essays collected in The Character of Economic Thought, Economic Characters, and Economic Institutions (1996) and the magisterial two-volume The Pillars of Economic Understanding-Ideas and Traditions and Factors and Markets (with Charles R. McCann, Jr. 1998, 2000). Viewed in this light, Perlman's idea to edit a volume on Schumpeter and his Contemporaries appears to be a natural continuation of his lifelong endeavor to reconstruct the world of economic thought in general and of Schumpeter in particular. The editors of this volume modestly strive to live up to Perlman's spirit.

As a historian of economic thought, Perlman did not follow the familiar practice of confining his study to the works of dead economists, but he was in equal measure a

Uwe Cantner

uwe.cantner@uni-jena.de

Kurt Dopfer

kurt.dopfer@unisg.ch

1 Lehrstuhl für Volkswirtschaftslehre/Mikroökonomik, Fakultät für Wirtschaftswissenschaften,

University of Jena, Carl-Zeiss-Straße 3, 07743 Jena, Germany

2 University of St. Gallen, St. Gallen, Switzerland 
participant observer in the ongoing discussions of contemporary theory formation. As a student, he met Schumpeter in person, but - perhaps more importantly - he maintained numerous and varied personal contacts with several of Schumpeter's students, including Wolfgang Stolper, Paul Samuelson, Richard Goodwin, Shigeto Tsuru, and Eduard März.

Perlman also excelled as an institutional entrepreneur who, in the $1980 \mathrm{~s}$, contributed in essential ways to the take-off and subsequent rapid development of evolutionary and Schumpeterian economics. He was a founder and executive editor of the Journal of Economic Literature, as well as co-founder and committed co-editor of the Journal of Evolutionary Economics. In addition, he was instrumental in founding the International Joseph A. Schumpeter Society, which houses this journal, and served as editor of many of the biennial conference proceedings volumes.

This special issue gathers 25 papers from distinguished economists or historians of economic thought. Fate did not grant Mark the pleasure of completing this editorial project, and we can but imagine how fascinating his picture of Schumpeter's world would have been. It remains - as a privilege - for the second generation of participant observers to complete this task. Given the wide scope of the general subject matter, completeness could hardly be expected, and from an editorial point of view it would have been an unrealistic goal to pursue in the first place. However, the enormous variety of viewpoints, diversity in focal emphasis, and interpretive richness of these papers allow for mirroring faithfully Schumpeter's personality — as a polymath and as a man of universal stature.

Schumpeter was a well-travelled man. He travelled widely in Europe and lectured in the US many years before his move to Harvard. He travelled to Japan in 1931, at a time when transcontinental travel was still undertaken by ship and when the Japanese bid farewell by toasting with a glass of water, as it was generally not expected they would ever see a person again who was travelling to a place as far as Europe.

While his voyage to Japan was spectacular in terms of geographic distance, Schumpeter's travels in the Western hemisphere were informed not only by a geographic map, but also, and above all, by an intellectual one. His major destinations were locations where modern economic theory was in the making. In these places, Schumpeter's ideas were formed and, in turn, he left lasting marks in the discipline of economics. His journey started in Vienna, the center of the Austrian School, followed by an interlude in Berlin and Bonn, sites of the German Historical School, and, finally, to Cambridge, Massachusetts, where, at the Harvard Circle, he influenced a young generation of economists who themselves were to shape the course of modern economics in the decades to come.

The overall content of the volume is divided into three parts:

- The first part assembles papers of a more general nature that highlight the historical contingency of "bourgeois virtues" of early and late capitalism and the socioacademic background related to topical themes that ruled the scientific discourse in the 'circles' of Vienna and Harvard.

- The second part includes papers that deal with the relationship between Schumpeter and his colleagues. Much as with Perlman, Schumpeter was a participant observer, and a number of colleagues, including his teachers Eugen Böhm von Bawerk, Carl Menger and Gustav von Schmoller, came to figure in his History of Economic Analysis. 
- The third part comprises papers that deal with Schumpeter and his students. Schumpeter did most of his teaching through his "Harvard Circle" which, in many ways, resembled the kind of Circle (Kreis) he experienced in Vienna in his formative years. These "Circles" were communities the members of which may, in a discourse or over some time, change their roles, sometimes assuming the part of teacher, sometimes that of student - where the teacher was only distinguished by the greater generation of new knowledge.

\section{Historic Societal Contingence and Intellectual Postures}

Part 1 commences with a paper by Charles McCann titled Mark Perlman: The Schumpeterian Influence. McCann identifies the influence Schumpeter had on the work and ideas of Perlman who later set out to analyze Schumpeter's influence on the work and ideas of other contemporaries. The self-referential twist of this enquiry provides unusual insights into the work of both Perlman as the progenitor of the present project and Schumpeter as its designated subject matter. Generally, the early Schumpeter is seen "to have been in the Cartesian mould", with economics representing a "scientific discipline, distinct in kind from political economy, a logical and mathematical discipline, ahistorical by its nature" (25); in turn, the later Schumpeter became more Baconian, his "grounding in economic history, sociology, statistics, law, political science, political economy" (25). Perlman arguably adopted the posture of the later Schumpeter, but unlike Schumpeter, Perlman recognized the necessity of acknowledging expressly the "significance of Institutionalism as a school of thought and as a subject of inquiry" (25). In the concluding section of his contribution, McCann quotes Perlman: "As with Einstein, Schumpeter failed to find his unified theory, but like Einstein he believed that there must be one somewhere" (Perlman 1994, xxxvi). Indeed, one may opine that despite Schumpeter's broad vision of a unified economic theory, his project was bound to remain unfinished given his ultimate reluctance to import the required knowledge (from sociology, psychology, etc.) not native to the traditional canon of the economic discipline.

Paul A. Samuelson, in his paper The Harvard Circle (title inserted by editors), provides an "undocumented memory" report which is remarkable in two ways. First, his chronicle of personal encounters and reminiscences bears witness to the extraordinary number of now famous economists who, in the years around 1935 gathered in the "Harvard Yard". It also reveals spectacularly how close interactions between scientists can spur great scientific advances. More important in the context of this volume is Samuelson's paper as an assessment of Schumpeter's work. It provides a clear indication of how his own work departed from Schumpeter's, leading to what in hindsight may be conceived as a major bifurcation in the evolution of contemporary economics. Schumpeter aimed at completing economics by amending Walras' equilibrium theory with a dynamic chapter focusing on entrepreneurial innovations and by relying on a mix of methods. In contrast, Samuelson set out to complete the neoclassical program by integrating the domains of micro- and macroeconomics based on comparative equilibrium statics, inspired by Newtonian physics and clothed in rigorous mathematics. In his paper, Samuelson criticizes Schumpeter for being "such a bad macroeconomist ... as 
bad as 1931 Hayek" (33), and scolds Schumpeter for "having admiration for technicians whose mathematical nuances he did not fully understand" (34).

Samuelson the Schumpeter student sets the pace for modern neoclassical economics, much in the Cartesian spirit of the young Schumpeter, and it was not before the 1980s, mostly due to the influential work by Richard R. Nelson and Sidney G. Winter, that Schumpeter's key theoretical message of the innovative entrepreneur as the driver of modern capitalism gained broader credence in the discipline. In due recognition of Schumpeter's lasting contribution, Samuelson concludes: "What will ever be remembered was his now century old emphasis on entrepreneurial innovation as a cardinal catalyst for economic progress" (34).

In his paper Joseph Schumpeter: The Long Run, and the Short, William J. Baumol gives Schumpeter's purported Achilles heel (lack of understanding of macroeconomics and of mathematical sophistication) a different interpretation. Baumol does not start off with static Keynesian macroeconomics developed around the critique of Say's proposition of an automatic macro-equilibrium, but instead refers to the central contribution Say made with a view to modern economic dynamics, stating "it is only Say who recognized and, indeed, emphasized the role of the innovative entrepreneur, who perceives the promises of an invention and takes steps to ensure that it is put to effective use" (40). Thus departing from the 'dynamic Say', Schumpeter's seminal contribution comes into focus. Baumol sketches Schumpeter's "workable and useful micro-model of the growth process" demonstrating - in appreciation of Schumpeter's 'tacit' technical skills - that "his model lends itself directly to formalisation" (42).

Gunnar Eliasson's paper, The Incomplete Schumpeter Stockholm School Connection, is an exercise in counterfactual history of economic thought inspired by the "sad observation ... that unique constructive features of two schools - the Austrian/ Schumpeterian and the Swedish Stockholm School-have been dispatched into ignorance for such a long time" (54). The counterfactual approach enlarges the context of interpretation, indicating connections between theories or schools that evade any analysis conducted on the basis of a factual account. Here, the Schumpeterian entrepreneur emerges in the context of dynamic coordination failures defined by Wicksellian cumulative processes, in the sequential analysis of Stockholm school economists, in Carl Menger's subjectivist focus on ignorance, and in Hayek's discussion of investment mistakes - all loosely posited in a framework that distinguishes between ex ante and ex post.

In her paper, It was Ideas and Ideologies, not Interests or Institutions, which Changed in Northwestern Europe, 1600-1848, Deirdre N. McCloskey traces a historical path that has led to what Schumpeter called the "business-respecting civilization". In her view Schumpeter's ensuing theoretical edifice suffers from the basic shortcoming that he "did not ... attempt to unify his economics of entrepreneurship with sociology ..." (57). Schumpeter's case is seen as symptomatic for the general neglect of integrating properly the various disciplines of the social sciences. In a general attempt to shatter "bad history, bad economics, and bad sociology", McCloskey endeavors to rewrite chapters of European history such that "better ideological conditions" and improvements in the "conditions of talk" are the driving forces. The materialistic underpinnings of traditional histories are dismantled, not sparing the venerable figures Toynbee and Mantoux, and the "memes" of the bourgeoisie are given distinct explanatory power. In its instrumental avenues, "Science didn't make the modern world. Technology did, in 
newly liberated and honoured instrument makers and tinkerers." (64) From here a bridge may be built to the Schumpeterian entrepreneur who is not interested in ideas per se but rather in ideas as the basis for carrying out economic operations.

Paul Nightingale's paper Schumpeter's Theological Roots?: Harnack and the Origins of Creative Destruction, demonstrates that Schumpeter's "creative destruction"- a concept associated with the very core of his work-was paralleled by Harnack's historical analysis of religions such as Christianity. The parallels exist at the overarching plane of an assumed general historicity, as "(f)or Harnack, Strauss, Ritschl and Schleiermacher, the Bible was not an expression of timeless truth but a product conditioned by the historical context in which it was produced." (70) The statement evokes (as analogy) neoclassical decision logic as "timeless truth" and leaves evolutionary economics as analysis of actual economic phenomena produced in a "historical context". More specifically, the close parallels also appear at the theoretic level as manifest in Harnack's proposal to re-structure the "history of Christianity ... around a dynamic theory of historical change driven by charismatic innovators, revolutions and the creative destruction of old orders" (70). Nightingale suggests we "reread Schumpeter with fresh eyes" (74).

Based on the exegesis proposed, we may also wish to address the foundational question of whether evolutionary economic theory should be considered as a special theory within a more general theory of social evolution - a question much underresearched but arguably as relevant as the enquiry into a homology between biological and economic evolution.

\section{Schumpeter's Colleagues}

Richard Arena furnishes some "basic elements" aimed at identifying compatibility and non-compatibility with regard to intellectual background and theoretical thinking of Hayek and Schumpeter in his paper On the Intellectual Foundations of Hayek's and Schumpeter's Economics: An Appraisal. In essence, while both were "Austrians" in advocating methodological individualism, Hayek gave it a strictly "subjectivist" interpretation, whereas Schumpeter's is "objectivist". Viewed from this angle, Hayek "excludes the use of standard macroeconomic theory" while Schumpeter turns into an "enthusiast for macroeconomics" (81), leaving Schumpeter as a macroeconomist apparently not "as bad as Hayek" (following Samuelson). In Arena's reading, the objectivist stance explains Schumpeter's "holistic" orientation when explaining economic coordination and his proclivity for social classes and institutions.

Hayek's and Schumpeter's approaches are seen to converge in the domain of monetary theory and of credit organization, which is "at the centre of Hayek's as well as Schumpeter's business cycle theory" (84). Both built on the legacy of their Austrian masters, such as Menger and Böhm Bawerk, and drew on the Wicksellian analysis of credit and productive activities.

In his paper Schumpeter and Mises as 'Austrian Economists, Viktor J. Vanberg addresses the question of Schumpeter's “Austrian-ness" from the perspective of Mises' work, particularly as it informed that of Neo-Austrian economists, such as Israel Kirzner. Vanberg eschews the early views of a "paradigmatic divide" (91) that leaves Mises as "the true messenger of the Mengerian heritage". In contrast, Schumpeter is the 
"renegade who departed from constitutive tenets of the Austrian paradigm" (91). While there remain considerable differences over the feasibility of socialist planning and the historical viability of socialism, their shared "Austrian" picture of the individual as an active economic agent is more emblematic of the relationship between the two. Within this common framework, Mises' theory is seen to represent the more general case because "entrepreneurship is not only exhibited in the more spectacular acts of "creative destruction' but constitutes the essence of the market process as such ...." (101). In this way, Schumpeter's entrepreneur comes to operate in a market context that is composed of agents who are all "entrepreneurs", and Mises' generalized market picture is enriched with Schumpeter's special, incessantly equilibrium-destroying entrepreneur.

In his paper, The Best Horse in the Viennese Stables: Gottfried Haberler and Joseph Schumpeter, Stephan Boehm introduces a man who "knew Schumpeter as a mentor, colleague and fatherly friend for almost 25 years", an ideal qualification for serving as Schumpeter's biographer. Following in the footsteps of Schumpeter, "Haberler excels as a master of the biographical essay, judiciously blending Schumpeter's outer life with his work ..." (110) While Perlman was a participant observer, as one of Schumpeter's "students", Haberler's observer status was as one of Schumpeter's colleagues.

In many ways, Schumpeter and Haberler were very close, owing to their common Austrian roots; yet they were not tuned to the same wavelength in their theoretical orientations. In his Prosperity and Depression, Haberler "offered a systematic survey of monetary and non-monetary theories of the business cycle, aimed at a synthetic explanation of the nature and causes of booms and slumps" (108). He "used to discuss the various theories under the heading of: upswing (prosperity), upper turning-point (crisis), downswing (depression), lower turning-point (revival)" (108). The first edition (1937) was well in accord with Keynes' macroeconomic framework and it was for him easy to integrate fully Keynes' theory in the second (1939). In Schumpeter's view, economic cycles were caused endogenously by innovative entrepreneurs and credit creation $(1912,1939)$ and there is little doubt that the nature of his cycle theory cannot be grasped without due recognition of his Theory of Economic Development (1912). Haberler's student Samuelson aimed at a synthesis between static neoclassical micro and short-run Keynesian macro theory. Against this background, it is easy to understand why, according to Boehm's trouvaille, Samuelson confided to Haberler: "I got more from you in the 1936-1940 period than from any other scholar" (114).

Harald Hagemann introduces another lifelong friend from Schumpeter's student days at the University of Vienna in Capitalist Development, Innovations, Business Cycles and Unemployment: Joseph Alois Schumpeter and Emil Hans Lederer. Among their teachers were Carl Menger and Friedrich von Wieser, but, following Hagemann's reading, "of particular influence on Schumpeter as well as on Lederer was Eugen von Böhm-Bawerk's famous seminar in 1905-1906." (119). It was then that "both Schumpeter and Lederer first developed a greater interest in Marxian analysis" (120). As their later contributions reveal, they were actually not influenced by Böhm Bawerk's theory itself, but rather by his critique of Marx, upon which they advanced their counter-critique and developed their own theories. This dialectic is paradigmatic for the climate that prevailed in Vienna at the time, where not only did many theoretical ideas get their distinct profile but as well obtained new intellectual shape in varied forms of synthesis. To wit, Lederer, who expressly built on Marx, held that "in contrast 
to Marx capitalism is not a sick economic system doomed to collapse, but a wellconstructed economic system whose substance is stable" (122).

Both Schumpeter and Lederer proposed a clear distinction between the short run and long run, and, consequently, they shared essential elements of theoretical vision and problem focus. In accordance with Schumpeter, Lederer held that the "cyclical fluctuations are an endogenous phenomenon inseparably linked with the long-run growth process of a capitalist economy" (126). Particularly, he made Schumpeter's view of forced savings "an integral part of his theory" (125), in this way advocating credit to be spent ex ante for innovative investment activities and thus eschewing the Hayek-Mises theory that points to its inherent dangers of inflation and overinvestment. As for policy, Lederer followed Keynes' macroeconomic line by acknowledging expressly the (un)employment problem. However, he was still in consonance with Schumpeter's view when it came to "technological unemployment", though, unlike Schumpeter, Lederer did not rule out a situation in which technical progress was too fast and could be a main cause of lasting (not only temporary) unemployment.

In their paper, The Schumpeter-Hilferding Nexus, Panayotis G. Michaelides and John G. Milios highlight the relationship between Schumpeter and Rudolf Hilferding, yet another colleague who joined Schumpeter in the Böhm-Bawerk seminar in Vienna. Similar to other Austrians, Hilferding entertained a long-run view, and Michaelides and Milios observe that his definition of economic development "has striking similarities with Schumpeter's" (133). Acknowledging that Hilferding attributed economic development "to the opening of new markets, the establishment of new branches of production, the introduction of new technology and the expansion of needs resulting from population growth", Hilferding, in fact, is given priority concerning the general exposition of the theory of economic development usually attributed to Schumpeter. The authors' assertion that it was "Hilferding who first developed these ideas" (135) is interesting, though it also invites consideration of Hilferding's view of economic development primarily as a change in resource magnitude, e.g. population growth or market expansion. This is in contrast to Schumpeter's view of development as a process of carrying out new combinations by entrepreneurs and innovative firms, expressly refraining from any explanation on the basis of changes in "objective" magnitudes, such as population growth. Clearly, "future research would be of great importance" (143).

In his masterpiece Finance Capital (1910/1981), Hilferding distinguished between paper money, which is legal tender for purchasing a social product, and credit money, which represents a private "promise to pay" (141). As with Schumpeter, Hilferding proposed a causal nexus between the scale of production and the scale of credit circulation; but unlike Schumpeter, and much in the manner of Lederer, Hilferding considered the tendency for an upswing in a business cycle to stem from idle credit as furnished by the private banking system rather than from innovating entrepreneurs or firms. In the long run, however, they share the view that in the age of mature capitalism, technological conditions would inevitably lead to large-scale production and to capital accumulation concentrated in the hands of a few large firms or conglomerates. In this context, Hilferding's central hypothesis of a "tendency of finance capital ... to establish social control of production ... vested in an oligarchy" (139) may be seen to complement well Schumpeter's seminal hypothesis of a self-destruction of capitalism.

Heinz D. Kurz introduces a colleague who was a leading representative of the economics discipline in Germany in his paper The Beat of the Economic Heart: 
Joseph Schumpeter and Arthur Spiethoff on Business Cycles. Kurz writes, "Spiethoff played an important part in several crucial moments of Schumpeter's life and career and was a mentor of his younger colleague" (148). In their theoretical outlook, "[b]oth were first and foremost concerned with the endogenous dynamism of the capitalist economy and the cyclicity of economic development and growth" (148). Moving from Austria to Germany in the early decades of the last century is bound to bring us under the sovereignty of the Historical School, with Gustav Schmoller as its towering figure. Spiethoff, first a student, then an assistant and secretary of Schmoller, held him "in high esteem", but "he did not follow him in each and every respect" (149). Schumpeter, who insisted on drawing clear boundaries between economics and other disciplines, gave Spiethoff much credit for having resisted attempts "to merge economics into an allembracing sociology” (which was Schmoller's program). Schumpeter instead appreciated Spiethoff for remaining "a research worker strictly within the traditional boundaries of economics" (152).

Spiethoff's explanation of economic cycles — worked out in his Krisen (1925) and in his magnum opus Die wirtschaftlichen Wechsellagen. Aufschwung, Krise, Stockung (Economic Cycles. Upswing, Crisis and Stagnation) (1955) — combined the theoretical notion of a "typical pattern of the cycle" ("Musterkreislauf") with that of "economic style" ("Wirtschaftsstil") prevalent in an economic system at a particular point in time. In Spiethoff's view "there cannot be a single theory of business cycles, but there must be several of them, each attuned to the particular economic style congenial to it and at the same time allowing for the mutual and interactive transformation of both, style and cycle." (153) Characterizing his method, Spiethoff "spoke of "historical" and "observational theory" (geschichtliche or anschauliche Theorie)" (149). This conveys some of the subtlety of the methodological posture if we consider that the English term observational is well in tune with the tenets of positivism, while the German term anschaulich refers expressly to an evocation elicited through observation in the mind of an observer, something entirely incompatible with the positivist canon.

As with his Austrian colleagues Lederer and Hilferding, Schumpeter agreed with Spiethoff that economic cycles are endogenous and, in fact, he praised Spiethoff for being "the first to recognize explicitly that cycles are not merely a non-essential concomitant of capitalist evolution but that they are the essential form of capitalist life" (Schumpeter 1954, 1127; italics by Kurz, 152). Premised on this central view, they developed their distinct theories, yet it still explains their differences. As an example, Spiethoff, as with Lederer, views a cycle as starting "from idle resources that now find employment," while, in Schumpeter's view, it "starts from a 'circular flow', characterised by the full utilization of productive resources" (154). In another instance, "Spiethoff's entrepreneurs risk their own money" while in Schumpeter's view, in line with Hilferding's, they "risk bank money!" (155).

John Foster's paper, Joseph Schumpeter and Simon Kuznets: Comparing their evolutionary economic approaches to business cycles and economic growth, examines the connection between the work of Schumpeter and Kuznets, the latter "generally not classified as an evolutionary economist" but who, in line with Schumpeter, "adopted an evolutionary view of economic growth (and fluctuation)" (164). There is "no integration of their perspectives", a disjunction which, as Foster points out, is "an early example of the split that was to occur between American institutionalist and neo-Schumpeterian evolutionary economics" (164). 
Kuznets, an undergraduate student at the University of Kharkov in Russia, immigrated to the US in 1921 where he studied at Columbia College under Wesley Mitchell. In 1926, he gained his $\mathrm{PhD}$ under the supervision of Mitchell who invited him to join the National Bureau of Economic Research (NBER) where "he was doing pioneering work on the quantitative analysis of economic growth" (165). Kuznets tried to develop a theory of business cycles on the basis of "careful measurement, data collection and statistical comparisons", which served as a benchmark for criticizing Schumpeter's Business Cycles (1939) for not offering "proper quantitative analysis" and "hypotheses that can be tested statistically" (166). Instead Schumpeter "practised his own kind of inductivism, based on historical study rather than only on detailed statistical data" (167). However, Kuznets praised Schumpeter for his "monumental thesis", and he "clearly admired Schumpeter's bold and ambitious research programme but, being an institutionalist, [Kuznets] had little sympathy with intellectual machinations concerning deductive economic theory" (167).

Kuznets did considerable statistical groundwork regarding the "evolutionary analysis of economic growth where it is driven by differential growth in leading sectors that outweighs differential declines in mature sectors" (168). Schumpeter appreciated this work and discussed it with Kuznets, but he "seemed to regard Kuznets with a measure of aloofness, as a master tradesman might regard an apprentice trying to use new tools that were deemed useful but inappropriate for producing masterpieces" (169). However, as with Spiethoff, Lederer, Hilferding, and others, what counted in the end was the "fact that they both perceived economic growth as an evolutionary process" (170). Notwithstanding their differences, they offered "approaches to understanding economic growth and its fluctuation from a shared evolutionary perspective" (171).

In his paper The improbable econometric connection-Schumpeter and Frisch at the midnight of the century, Francisco Louçã investigates the relationship between Schumpeter and his 12-years-younger colleague, Ragnar Frisch. When the two first met at Harvard in 1927, Schumpeter "had a previous intense career as the most frequently quoted economist in the first decades of the century", while Frisch "was just a young economist with no publications" (173). Their biographies lay worlds apart, considering that Schumpeter had found it difficult to form an opinion about whether the events in Germany after 1933 "may mean a catastrophe ... (or) salvation" while Frisch, a committed socialist, spent a year in a concentration camp as the Nazis invaded Norway. "Yet these differences did neither prevent nor affect their long-life relationship" (176), and did not restrain them from getting involved in the common project of creating "econometrics as the tool to reconstruct economics as a mathematically based social science" as well as to engage in the foundation of the "Econometric Society" (173).

Inspired by discussions with Schumpeter, "Frisch formulated his own impulsepropagation model of cycles which would gain him, much later, the first Nobel Price in economics" (178), together with Jan Tinbergen. Frisch's "sophisticated model of a mixed system of difference and differential equations plus shocks ... became the paradigm for the representation of the mechanics of cycles" (178). In turn, "Schumpeter's lifelong project was to create a general theory" that supplemented that of Walras' by explicitly recognizing that "there was a source of energy within the economic system which would of itself disrupt any equilibrium that might be attained" (178). While Schumpeter described this endogenous drive as "a very complex causal system, Frisch represented this same system as a mechanism of a pendulum swinging 
back and forth" (178). Schumpeter derived the cause of fluctuations from the inner drive of the capitalist system, much in tune with the theories of the Austrians and the strands of modern Neo-Schumpeterian economics. In contrast, Frisch, well in consonance with Samuelson's approach, entertained a mechanistic mode of analysis that attributes change to outside factors, an approach alien to evolutionary thinking.

In his paper, Understanding inescapable modernization: Werner Sombart and Joseph Schumpeter, Manfred Prisching investigates the relationship between the German Sombart and the Austrian Schumpeter. Sombart, born in 1863 and thus 20 years older than Schumpeter, got his first professorship at the Prussian University of Wrocław (then Breslau) in 1890, but his further academic career was delayed as he had awakened the suspicion that "he leaned towards socialist ideas" (186). Eventually, Sombart followed Adolph Wagner as department chair in Berlin in 1917. As a co-editor of the distinguished Archiv für Sozialwissenschaft und Sozialpolitik, Schumpeter was well acquainted with Sombart, who is said to have sided with the group opposing Schumpeter's appointment to the chair in Berlin.

Sombart's masterpiece is his Der moderne Kapitalismus (1928), "a huge work in six volumes which deals with capitalism from its outset in the 13th century up to its "final stage' at the time of World War I" (193). Sombart influenced Max Weber in formulating his celebrated thesis that religion was the driving force of capitalist development, but Sombart proposed that additional "social factors", epitomized in the "bourgeois spirit", were relevant: "The bourgeois spirit wants to order and preserve, it is moderate and diligent, it is committed to commercial solidity and parsimony. Bourgeois virtues have to overcome the traditionalism of handicraft as well as the adventurism ...." (189). Schumpeter's entrepreneur - driven by "adventurism"-is put into a societal context defined by the social formation of "bourgeois capitalism". The bourgeois nature is a "complement to the adventurous spirit" (189).

In his Die drei Nationalökonomien (1930, Three kinds of economics), Sombart "adopted Windelband's and Rickert's distinction that the natural sciences and the humanities are characterized by different methodologies" (191). He proposed that the humanities, unlike the natural sciences, should conduct their inquiries on the basis of "hermeneutics, inner experience, intuition, historical uniqueness" (191). Sombart shared with Max Weber and also (as mentioned earlier) with Spiethoff the approach of a verstehende Ökonomie (192). In Prisching's summary, "Sombart, Schumpeter and Weber were similar in their ideals what social science studies should look like, but actually Sombart focused on the historical, Schumpeter on the economic and Weber on the sociological aspects" (192).

David B. Audretsch seeks to provide a link between the works of Schumpeter and his young colleague Galbraith in a paper entitled Joseph Schumpeter and John Kenneth Galbraith: Two Sides of the Same Coin? After completion of his undergraduate studies in Toronto, Galbraith studied at Berkeley where he received his $\mathrm{PhD}$ in 1934. Two years later, at age 25, he became an instructor of economics at Harvard and Schumpeter's colleague for 5 years. In 1937, he spent time in Great Britain, which brought him in contact with Keynes's trailblazing ideas about macroeconomics. After returning to Harvard, the young Keynesian-Institutionalist Galbraith participated in the discussions in Schumpeter's 'circle'. For political reasons, Harvard refused to appoint Galbraith as professor in 1939; an appointment came 10 years later, only a few months before Schumpeter's sudden death. 
Galbraith's "most seminal work and contributions ... read like an extension and application of the basic tenets introduced and developed by Schumpeter" (197). The major differences show up in Galbraith's view that the individual Schumpeterian entrepreneur has no role to play in capitalism and, consequently, the associated "concept of creative destruction as the driving force of innovation, growth and economic development is noticeably absent" (200). Galbraith explored the institutional aspects of the "techno-structure" of modern large-scale corporations and highlighted their politico-economic inter-connectedness with The New Industrial State (1967/ 1979). Here, market power is highly concentrated in the hands of a few large corporations, and coordination of production and consumption takes place primarily at the level of collective units such as big business, labor unions, consumer associations, and an active government. Coordination is brought about by establishing and maintaining a balance between all "countervailing powers" at an intermediate, or meso, level. The model is premised on the vision of continuity stated in terms of meso equilibria rather than in terms of entrepreneurial actions which turn economic coordination into an inherently discontinuous process.

The actual techno-economic revolutions in the 1970s and 1980s had their origins not in large-scale companies such as US-Steel, General Motors and AT\&T, but in individual Schumpeterian entrepreneurs who started a business, typically small-scale, in a "garage", and then established firms that sometimes evolved into corporate giants and major market players. In the early 1980s, these developments aroused renewed interest in Schumpeter's work, leading to a Neo-Schumpeterian program that addresses the nature of exactly this kind of evolutionary dynamic. In Schumpeter's dynamic framework, the entrepreneur carries out new combinations (micro) that are adopted by followers resulting in new industries and new markets (meso), and which, in a process of creative destruction, change the nature of production, consumption and markets of the (macro) economy qualitatively and quantitatively from within.

As indicated by Audretsch, Galbraith was one of the most popular economists of the 20th century. Nevertheless, it may also be worthwhile further contemplating why his work did not attract a great many economists at a time when there was a need for theoretical answers for the most pressing problems of the present economic époque, and why a Neo-Galbraithian program, similar to the Neo-Schumpeterian one, is still not around. Our hypothesis would be that Galbraith's static equilibrium-based view of an intermediate level proved largely unattractive when coping with the extraordinary innovation dynamic of the last three decades, while Schumpeter's dynamic interpretation proffered a wellspring of novel theoretical vistas, conceptual schemes, new hypotheses and new fields of empirical investigation.

\section{Schumpeter's Students}

In his paper, Schumpeter and Talcott Parsons, Richard Swedberg discusses the relationship between Schumpeter and Parsons. Parsons was Schumpeter's some 20-yearsyounger student whose work was to become instrumental in establishing sociology as a separate discipline in the US. Parson received his $\mathrm{PhD}$ in economics from Heidelberg University in 1927. He attended Schumpeter's classes at Harvard University in 1929, and "was immediately attracted to the type of analytical economics that Schumpeter 
taught and advocated" (217). Next to his interest in economics, Parsons "soon became fascinated by sociology, and when a department of sociology was created at Harvard in 1931, he decided to transfer there" (215).

In his early book entitled The Structure of Social Action (1937), Parsons proposed a theory that drew heavily on Max Weber and Emil Durkheim. In his subsequent book, Economy and Society (1956, co-authored with his student Neil Smelser), he tried to conceptualize society "as a social system consisting of four distinct sub-systems - one of which is the economy" (216). In the manner of his teacher, Parsons held the view that economics and sociology are distinct but complementary disciplines "with economists focusing on efficiency and the means-end relationship, and the sociologists on values and norms" (216). Furthermore, both cherished the tenet of a unified social science, with the sociologist Parsons advocating a "social systems" approach, and the economist Schumpeter, "social economics". Their relationship was mutually beneficial, as the young Parsons got his lessons from Schumpeter, while, in later years, through Parsons, "Schumpeter was able to keep an eye on what was happening in sociology" (220).

Inspired by a vision of a unified social science, both set out to circumscribe carefully the discipline of sociology and of economics, yet as most readers may concur, they both failed in the remaining task of demonstrating how the distinct, but complementary, disciplines may be integrated.

In Joseph Schumpeter and Wolfgang Stolper, Frederic M. Scherer records the relationship between the two, a relationship that arguably can be understood only against the background of the particular relationship Schumpeter maintained with Wolfgang's father, Gustav. In fact, Scherer's paper turns out to be in large part as much a paper on Gustav Stolper as it is on Wolfgang Stolper. Schumpeter and Gustav Stolper "evidently knew each other in Vienna in the 1910s to the time of Stolper's move to Berlin in 1925" (224). In 1925, Stolper wrote a letter to Bonn university professor Spiethoff intending to help Schumpeter "to rescue ... his good name" in the wake of the failure of Biedermann Bank. Two years later, Stolper, Spiethoff and others campaigned for Schumpeter's appointment to the University of Berlin, albeit unsuccessfully for reasons indicated earlier.

In 1930, Wolfgang studied law and economics at the University of Bonn, and when the Nazis seized power in 1933, he was, like his father, forced to leave Germany. He moved first to Switzerland and then "obtained, apparently with help from Schumpeter, and 'not without opposition,' fellowships for the first two years of graduate work at Harvard University" (226), where he received, as earlier in Bonn, "unique one-on-one tutorials" from his mentor (223). In 1938, he completed his PhD at Harvard under the supervision of Schumpeter and Haberler. Later, he became a professor of economics at several distinguished US universities.

Similar to other students of Schumpeter, Stolper did not follow faithfully the theoretical program of his teacher; instead, he engaged, to give but one example, in a cooperation with Samuelson, which resulted in the famous Stolper-Samuelson theorem. However, quite a few readers will remember the enormous tacit contribution Stolper made to the Schumpeter community in the 1980s and 1990s. Late in life, he wrote an important biography about Schumpeter and, along with Mark Perlman, was instrumental in founding the International Joseph A. Schumpeter Society.

In his paper, Eduard März and Joseph Schumpeter, Kurt Rothschild discusses the relationship between Schumpeter and März, "that fascinating immigrant", as James 
Tobin writes in his preface to the English translation of März's book on Schumpeter. März studied economics at the Economics University of Vienna (then Hochschule für Welthandel) and political science at the University of Vienna, but at the age of 25, shortly before he "could finish his studies in 1938 Hitler invaded Austria and Märzbeing a Jew-had to leave the country." He "arrived shortly before the war via Switzerland and Turkey in the United States" (230), where he again took up his studies at Harvard, attending "lectures of such outstanding economists as Schumpeter, Haberler, Hansen, and Chamberlain" (230). On his return in 1945 from his voluntary service in the US Navy, "he took up his $\mathrm{PhD}$ studies under Schumpeter which he finished in 1947 with a dissertation on the economic consequences of the break-down of the Habsburg Empire" (230).

März came in contact with Austro-Marxism in "Red Vienna" in the inter-war years, and later witnessed the controversy about Keynes' new macroeconomics at Harvard. Both influenced him profoundly, such that März's work "can be said to rest on three pillars: Marx, Schumpeter, and Keynes" (230). Schumpeter was certainly primus inter pares, as demonstrated by März' articles about Schumpeter's economic theory and by Schumpeter's influence on März' theory. There were many commonalities between the two, including their "common Austrian background", their "strong interest in history and the awareness of its importance for economic analysis", and, with regard to personal characteristics, "a certain similarity in attitudes and personality" (232). In Rothschild's assessment, "among all the economists who taught at Harvard in Schumpeter's days none had such a special position as this Austrian immigrant" (232). His relationship reminds us of those Schumpeter maintained with Haberler and with Wolfgang Stolper.

In their paper, Erich Schneider: The Admiring Disciple who did not become a Follower, Georg D. Blind and Andreas Pyka highlight the relationship between the Austrian Schumpeter and his Prussian student, Schneider, for whom "Schumpeter represented the rare occurrence of a genius", but who also instructed Schumpeter in mathematics. Born in 1900, Schneider began studying mathematics in Giessen, then moved to Frankfurt where he studied Pareto, Walras, Marshall, Thünen and Cassel and, at the age of 21, received his doctorate with a dissertation on Debt, Money and its Calculus (1923). Unsurprisingly, "mathematics, neoclassical microeconomics, and money were to stay recurrent topics throughout his life" (240).

Shortly before his appointment as a professor at the Danish University of Aarhus, Schneider "started a correspondence with Schumpeter in Bonn that led to a long series of weekly meetings from 1929 until Schumpeter's departure for Harvard in 1932” (240). In 1946, Schneider moved from Aarhus to Kiel, first accepting an invitation to become a professor at Kiel University and later Director of the Institute for the World Economy, where Jan Tinbergen and others were frequent guests. In Kiel, Schneider wrote his fourvolume text, which was to become the leading German-language economic text for years to come. He continued his communication with Schumpeter, and "thanks to Schumpeter's support Schneider obtained a Rockefeller grant for 1949/1950” (242). After spending some time at Harvard, he "met again with Schumpeter to bid farewell on January 7, 1950. During the following night Schumpeter suddenly died" (242).

As Schneider's and Schumpeter's research orientation differed, it is not surprising that they failed to acknowledge each other's works in great measure. Schumpeter refered to Schneider only occasionally. Schneider, in turn, almost never cited 
Schumpeter's seminal Theory (1912) However, in an article on economic growth, Schneider introduced explicitly the Schumpeterian perspective. He distinguished "four perspectives on economic development: a) specific developments as economic history, b) economic development in general, c) conditions for economic growth in general, d) conditions for steady-state growth in particular." Schneider "not only acknowledges that Schumpeter's focus is on type-b development, but also contends that no insights for Schumpeterian development can be drawn from perspectives c) and d)" (247). After Schumpeter's death, Schneider, together with Arthur Spiethoff, published all of Schumpeter's German-language articles in three volumes. Blind and Pyka portray a relationship between two men who could not have been more different, yet who had an extraordinary relationship based on deep mutual respect.

In Richard Abel Musgrave and Joseph Alois Schumpeter: Two intellectual authorities in economics and their shared and different frameworks, read through the lenses of the Perlman dichotomies, Helge Peukert analyzes the relationship between Schumpeter and Musgrave, who "at least in his younger years was not only a student but also an admirer of Schumpeter" (254). Musgrave, born near Frankfurt almost 30 years after Schumpeter, studied economics in Munich and Heidelberg, and was "influenced by the afterglow of the historical school and (German) early Keynesianism" (254). He went to the US with a stipend from the German Student Exchange Service in 1933, but remained there when hearing about the dismissal of most of his teachers at the university institute and facing threats himself because of his Jewish background. He received his MA from Harvard in 1936, his PhD with $\mathrm{H}$. H. Burback a year later, and subsequently served at Harvard as instructor. In 1948, he joined the department of economics at the University of Michigan, where his friend Wolfgang Stolper was among his colleagues and where he wrote his most important book, The Theory of Public Finance (1959). Musgrave returned to Harvard in 1965 to serve as H. H. Burback Professor from 1965 until his retirement in 1981.

Schumpeter and Musgrave had a common German-speaking background, and scientifically, "they both rejected the paradigm of an ever-equilibrating economy" (254) and they both had "a broad economy and society perspective" (255). However, their theoretical views diverged; Musgrave took no stock in "breakdown theories of capitalism, whether Marxist or Schumpeterian" but rather found solutions for the problems of late capitalism, in his own words, in "the responses of a flexible social structure and in a public policy that adjusts itself to the needs of changing situations" (254). He entertained the normative vision of a "good society" which, when translated into policy measures, "supported broad-based income taxation, a Keynesian fiscal role of stabilization" (258), and the like, all of which Schumpeter was critical.

Peukert uses "Perlman's navigation lights" when comparing Schumpeter and Musgrave, concluding, "Schumpeter came closer to the average American mind in sharing the alleged Leviathan misgivings in contrast to Musgrave who was in favour of extended state activities" (260). In turn, Musgrave scored better in that "he believed in the ... basic democracy", which Schumpeter "substituted with his somewhat cynical selection of the 'leadership only' approach" (260); and, as most readers may wish to add, the average American mind was even less prepared to swallow Schumpeter's vision of a "March into Socialism".

In his paper Shigeto Tsuru and Schumpeter, Yuichi Shionoya highlights the relationship between Schumpeter and his student Tsuru who "greatly respected Schumpeter 
... (though) he never accepted Schumpeter's ideas" (264). In 1935, after 2 years at Lawrence College in Wisconsin, Tsuru entered graduate school at Harvard, joining classmates Stolper, Musgrave and Samuelson. In 1940, Tsuru finished his PhD thesis under Schumpeter on the theme Development of Capitalism and Business Cycles in Japan 1868-1897 (1940). Samuelson, who, in his contribution to this volume, reckons Tsuru as one of Schumpeter's students, says elsewhere of him: "Ten years at Harvard and a key player in the post war MacArthur Administration, he was Schumpeter's personal assistant and a recognized expert on Keynes and Marx" (Tsuru 1994).

Following Shionoya, "Tsuru felt kinship with Schumpeter by virtue of the fact that the latter highly valued Marx's vision" (265). However, Marx is seen as reflecting not only the commonalities but also the profound differences in their worldviews and economic theories. Tsuru "doubts Schumpeter's thesis that the process of capitalist development would bring about socialism automatically without class struggle and revolution, as was argued by Marx" (267). In Tsuru's own words, Schumpeter fails "to combine the logic and practice of changing the social system" (267). In Tsuru's view, “although Schumpeter's theory looks like an institutional analysis, it is not a full-dress inquiry but is composed of the rhetoric of paradox. .... and paradoxes were decorations for his style of economics"; beyond that, "they were .... also makeshift means for avoiding serious inquiry into the problems in question" (267). Tsuru argued that innovations are not specific to capitalism but may be observed in all economies and that, therefore, explaining capitalism on the basis of innovations and ignoring the institutions characteristic of capitalism is ill-conceived. In particular, "Tsuru criticized Schumpeter for abstracting those institutional elements that are responsible for crises in the capitalist economy and for attributing the cause of business cycles to innovation, which transcends institutional specificity." (269)

From the 1970s on, Tsuru developed further his institutional economics, focusing particularly on environmental issues. He expounded his vision of a future economics in his Towards a New Political Economy (1976). In Tsuru's subsequent works, Kapp, Myrdal and Galbraith came to occupy a central place. His works along this line were published, for instance, as Mattioli lectures at Bocconi (1993), as mentioned by Shionoya. A full collection of papers is also available in two volumes, The Selected Essays of Shigeto Tsuru (1994), published in the Elgar Series Economists of the Twentieth Century, with Perlman and Mark Blaug as General Editors.

Hardy Hanappi explores the relationship between Schumpeter and his student Richard Goodwin in his paper, Schumpeter and Goodwin. Born in Indiana, Goodwin was 25 when he came to Harvard in 1938. After graduation, he left for London but soon returned to Harvard to become Schumpeter's assistant. Goodwin's stay in England brought him in contact with Keynes and with British Marxists, including the historian Eric Hobsbawm who became a close friend. At that time, and as part of an "anti-fascist community", Goodwin became a member of the Communist Party of Great Britain. When back at Harvard, he criticized, in lectures and publications, Keynes' macroeconomic production function on grounds that "linear first-order difference equations" based on 'Keynes' accounting framework and some crude assumptions on the constancy of socio-psychological propensities" were "much too simple" to capture the real dynamic of a capitalist economy (283). 
As with Schumpeter, Goodwin had a view of a "pulsating capitalist economy" but unlike Schumpeter, he modelled it "without innovation induced cycles" (285). The Goodwin-cycles share the logic of the Frisch cycles referred to earlier. Unlike Frisch, Goodwin lived long enough to witness the advent of mathematical 'chaos theory' which led him to restate his models more generally as discrete, iterated, non-linear models - a formal approach that robbed the models of their predictive power.

The mathematical developments along chaos theory have much enriched the field of economic dynamics, yet at the same time they have arguably diminished greatly its usefulness as a tool for economic policy, as was envisaged by Frisch, Tinbergen, and Goodwin. Thus, we observe a recurrent pattern in science: the greatest theoretical advances concur with the recognition of their ultimate limitations. Chaos-theoretic developments as pioneered by Goodwin were not only theoretical advances in their own right but they have also shown the limits of this kind of modelling and the need to introduce genuine evolutionary models.

In Schumpeter, Minsky and the Financial Instability Hypothesis, Mark Knell highlights the relationship between Schumpeter and his student Hyman Philip Minsky. Born in 1919, Minsky studied mathematics and economics at the University of Chicago. In 1942, he joined the post-war planning research project under the direction of Leontief at Harvard, where he "would have likely met Schumpeter" (294). Having served a few years in the US military and administration, Minsky "decided to return to Harvard University in 1946 to resume his graduate studies". After graduation, he "began his doctoral research under Schumpeter, but finished it in 1954 under the supervision of Leontief" (294). Minsky was “appointed Professor of Economics at Washington University in St. Louis in 1965, where he remained until his retirement in 1990" (294).

As other students of Schumpeter, Minsky was an admiring disciple, but one who did not follow in Schumpeter's theoretical footsteps. He "learned about the role of banks in financing investment from Schumpeter, but he followed an approach similar to that of Keynes" (295). The "financial instability hypothesis .... stands at the centre of Minsky's many contributions to economics and provides a crucial link between Schumpeter and Keynes" (295). Minsky described cycles as "a situation where an increase in speculative investments would lead to over-indebtedness and financial fragility over the course of the business cycle, which might ultimately lead to an economic environment that is conducive to high inflation, debt deflations, a collapse of asset values and deep depressions" (295). As with Schumpeter, Minsky opposed a mechanistic interpretation of the business cycle, as was proposed by Frisch or Goodwin, and, much in line with Schumpeter, he eschewed any hydraulic version of Keynes' theory, as outlined in Samuelson's neoclassical synthesis. Unlike any of these authors, both Schumpeter and Minsky offered an endogenous explanation of the business cycle without relying on the contrivances of exogenous shocks. However, when explaining the origin of recurrent cycles, Minsky's view is post-Keynesian, and akin to that of Hilferding, while in Schumpeter's view economic cycles and development are driven typically by entrepreneurial activity and successive creative destruction.

In his paper, A 'Conservative Marxist' at Harvard: The Influence of Joseph A. Schumpeter on Paolo Sylos Labini, Mauro Sylos Labini discusses the relationship between Schumpeter and a student who, as did Minsky, attended Schumpeter's last classes at Harvard. Born 1929, Sylos Labini became acquainted with Schumpeter's Theory (1912) as an undergraduate at the University of Rome, and "when in the late 
40s he won one of the first Fulbright scholarships, this book persuaded him to go to Harvard to complete his graduate studies" (316).

"Schumpeter's influence was enormous"; yet, as with others of his students, "the Italian economist developed a different conception of the evolution of economics as a discipline ..." (312). Their striking differences show up in "their deep disagreement on the Adam Smith legacy and Schumpeter's notorious admiration for Léon Walras ... “(313). Sylos Labini was a classical economist informed by Smith's division of labor and market exchange, as well as the non-dismal variant of the classical canon of economic development. Unlike Schumpeter, Sylos Labini did not consider neoclassical theory a consolidation of classical theory, but instead he viewed the two approaches as being cut from radically different cloth. Building on the classical legacy, Sylos Labini reassessed Schumpeter's theory on the basis of "three specific processes: innovation, changes in market structures, and changes in income distribution" (314).

Sylos Labini "regarded as fruitless Schumpeter's struggle for a general theory of novelty and innovation", and instead, echoing the Historical School, sought "to distinguish conceptually between different historical stages in technological change and economic growth, each stage needing a different theoretical model to explain it" (317). He rejected Schumpeter's hypothesis of a secular tendency towards large-scale business and market concentration, and we may conjecture that he favored an explanation along the line of a co-habitation of large- and small-scale business based on indispensable complementarities.

Schumpeter was arguably a conservative Marxist in that he considered the March into Socialism a probable though not predetermined outcome. In contrast, Sylos Labini may perhaps not so easily qualify as a Marxian (despite the title of the paper which leads the reader to expect this), considering that he "was convinced that the strength of capitalism was its ability to change continuously and to adapt to new circumstances" (321).

\section{Concluding Remarks}

Our introduction has aimed at providing a précis of each of the 25 papers in this volume. We have added biographical data in a few cases, have emphasized some aspects over others to indicate connections between the varied views presented in the papers, and we have also added some comments whenever deemed helpful to clarify an issue that arguably invites further reflection. In the course of developing this publication, we were saddened to learn that two contributors will not see its publication: Paul Samuelson died in 2009 at the age of 94, and Kurt Rothschild in 2010 at the age of 96.

Perlman's project idea was an indispensable source of inspiration for editing this volume. As editors, we concur fully with Perlman's fundamental belief that the study of the history of economic thought is essential not only for appreciating the legacy of the discipline's accumulated wisdom, but also, and most relevantly, for helping us to understand what is happening in the arena of present-day economics, as well as for imagining where the discipline is headed in the foreseeable future.

Contemporary information technology provides us with unprecedented tools for collecting, storing and organizing big data, and it so equips us with new ways of assessing scientific contributions on the basis of weighted and cross-referenced publication, quotation and citation indices. While this certainly goes with increased 
numerical objectivity, it also remains narrowly focused on the digital moment, with the relevant impact of ideas or scientific discourses that fail to meet those criteria left to fade in the background. These biases will compound as we extend the time-scale of measurement and assessment. In his The Character of Economic Thought, Economic Characters, and Economic Institutions (1996), Perlman quotes a novelist who provides a useful metaphor for dealing with the problem of objectively assessing scientific advance along a time scale: any rational author should be willing to trade 1000 readers at the time of publication, for 100 readers 10 years later or 10 readers 100 years later.

Schumpeter entertained a view of the economy as continuously changing, and it was the growing recognition of the significance of this idea that, over decades, has led to new ways of theorizing and to the emergence of a new field of inquiry that today we associate with evolutionary economics. The farewell to the dominant static-equilibrium view not only has led to new theoretical challenges, but it concomitantly also raises the more fundamental question of where the new approach is posited in the overall context of the discipline. How does evolutionary economics relate to other strands of the economics discipline? Is the relationship between neoclassical mainstream and evolutionary economics substitutive or complementary? Is Schumpeterian economics the very core of evolutionary economics, or is it but a particular, though essential, aspect of a more general evolutionary economic theory?

The assessment of the current research in the field will to a great deal depend on the kind of answers given to these or related questions. The contributions in this volume deal with events and ideas that cover a time span of roughly a century. Each of these contributions may serve as a source for enhancing our understanding of the broader context in which our ongoing theorizing, methodological work and empirical research are embedded and how these efforts gain meaning and validity. Each of the contributions contains indications as to how to develop further a theory of endogenous economic dynamics - the giant's shoulders provide a multifaceted, here and there still not fully integrated platform for further endeavors.

\section{References}

Galbraith JK (1967) The new industrial state. Houghton Mifflin Company, Boston

Haberler G (1937) Prosperity and depression: a theoretical analysis of cyclical movements. League of Nations, Geneva

Haberler G (1939) Prosperity and depression: a theoretical analysis of cyclical movements. Harvard University Press, Cambridge

Hilferding R (1910) Das Finanzkapital. Eine Studie über die jüngste Entwicklung des Kapitalismus. Wien, Wiener Volksbuchhandlung. English version: Hilferding, R., Finance Capital. A Study of the Latest Phase of Capitalist Development, Ed. Tom Bottomore, London: Routledge \& Kegan Paul, 1981

Musgrave R (1959) The theory of public finance: a study in public economy. McGraw-Hill, New York

Parsons T (1937) The structure of social action. A study in social theory with special reference to a group of recent European writers. McGraw Hill, New York

Parsons T, Smelser N (1956) Economy and society. Routledge \& Kegan Paul, London

Perlman M (1994) Introduction. In: Schumpeter JA (ed) History of economic analysis. Routledge, London

Perlman M (1996) The character of economic thought, economic characters, and economic institutions: selected essays. University of Michigan Press, Ann Arbor

Perlman M, McCann CR (eds) (1998) The pillars of economic understanding: ideas and traditions. University of Michigan Press, Ann Arbor 
Perlman M, McCann CR (2000) The pillars of economic understanding: factors and markets. University of Michigan Press, Ann Arbor

Schneider E (1923) Der Kalkül der Schuldverhältnisse, angewandt auf solche mit mehreren Geldsorten, insbes. die Geldarbitrage (Debt, Money and its Calculus), PhD thesis. University of Frankfurt, Frankfurt

Schumpeter JA (1912/1934) Theorie der Wirtschaftlichen Entwicklung. Leipzig, Duncker \& Humblot. English translation published in 1934 as The Theory of Economic Development, Cambridge, Mass.: Harvard University Press

Schumpeter JA (1939) Business cycles: a theoretical, historical and statistical analysis of the capitalist process, two vols. McGraw Hill Book Company, New York

Schumpeter JA (1951) Ten great economists. From Marx to Keynes. Allen \& Unwin, London, reprinted by Routledge in 1997 (with an introduction by Mark Perlman)

Schumpeter JA (1954) History of Economic Analysis, London: Allen \& Unwin; reprinted by Routledge in 1994 (with an introduction by Mark Perlman)

Sombart W (1928) Der moderne Kapitalismus. Historisch-systematische Darstellung des gesamteuropäischen Wirtschaftslebens von seinen Anfängen bis zur Gegenwart (Modern capitalism). Duncker und Humblot, Leipzig, finalized edition 1928

Sombart W (1930) Die drei Nationalökonomien (Three kinds of economics). Duncker und Humblot, Berlin Spiethoff A (1925) Krisen (Crises), Handwörterbuch der Staatswissenschaften, 6. Auflage, Band 4, 8-91

Spiethoff A (1955) Die wirtschaftlichen Wechsellagen. Aufschwung, Krise, Stockung (Economic cycles. Upswing, crisis, stagnation). J.C.B. Mohr (Siebeck), Tübingen

Tsuru S (1940) Development of capitalism and business cycles in Japan 1868-1897, Ph.D. Thesis. Harvard University

Tsuru S (1976) Towards a new political economy. In: Dopfer K (ed) Economics in the future: towards a new paradigm. Macmillan, London, pp 106-115, in Japanese (1979), transl. by S. Tsuru, Tokyo: Iwanami Shoten Publishers, 211-231

Tsuru S (1993) Institutional economics revisited, Raffaele Mattioli Lectures at Bocconi University. Cambridge University Press, Cambridge

Tsuru S (1994) Economic theory and capitalist society. The selected essays of Shigeto Tsuru, two volumes. Edward Elgar, Aldershot 